\title{
Poverty Reduction through Industrialisation, Economic Diversification and Growth in Low-income Countries: A Review of Literature and Evidence
}

\author{
Dr Cyrille Mabiata Nzobo \\ $\mathrm{PhD}$ centred on Public Policy and Economics, Coventry University, Department of International Studies and \\ Social Sciences, United Kingdom, Adjunct Associate Professor, De Mazenod University, School of Economics \\ and Management, Kinshasa, Democratic Republic of Congo, Independent Researcher and Consultant
}

\begin{abstract}
Poverty has consistently been a pervasive phenomenon tackled by public policies as it comes with its batch of intolerable levels of economic, social and political hardship deemed distressing for humankind. Thus, the strategy against this scourge gained increased attention within countries and across the globe. The poverty reduction strategy aims to pull people out of degrading living conditions. The debate on poverty reduction is of paramount significance because various approaches are suggested to address this issue, but with mixed results. That is because often, these approaches apply regardless of the circumstances of place and time. On this note, many keep attributing the success and failure of poverty reduction strategies in Low-Income Countries to the income distribution issue. Hence, this success and failure are thought to be linked to the adjustment between unlimited needs and the allocation of scarce resources required to address socio-economic issues formalised by poverty indicators. Engaged in another perspective, a great deal of literature and evidence suggests that the explanation of this success and failure could well be found upstream, namely, from the industrialisation, economic diversification and growth established as prominent tools to improve social welfare. Indeed, this literature and evidence contend that Low-Income countries are still struggling to manage poverty reduction as their economic circumstances exhibit weak industrialisation as well as inconsequential economic diversification and growth. This literature and evidence could be subject to scrutiny for a better understanding of poverty. Hence, this paper contributes to this debate by assessing selected literature and evidence. It establishes to what extent industrialisation, as well as economic diversification and growth, predispose Low-Income countries' ability and inability to encounter effectively the issue of poverty.
\end{abstract}

Keywords: Poverty, industrialisation, growth, economic diversification, low-income countries.

DOI: $10.7176 / \mathrm{JPID} / 60-04$

Publication date:July $31^{\text {st }} 2021$

\section{Introduction}

The debate on poverty reduction and the strategies used to end this multifaceted phenomenon is often cast as one of the public domain issues in which political as well as economic prescriptions clash (Ravallion, 2003) ${ }^{1}$. Poverty refers to the situation of a staggeringly large number of people living on less than $1 \$$ a day and does not have access to sufficient food, decent housing, drinking water, quality health care, education and all other elements of life in society (Banerjee et al., 2006) ${ }^{2}$. As such, poverty is a scourge so that governments seek ways and means to fight it. Therefore, poverty is well captured through a number of indicators that characterise it. Poverty indicators were encapsulated in the Millennium Development Goals (MDGs), which were extended under Sustainable Development Goals (SDGs) of the 2030 Agenda to incorporate health, education, income inequality, vulnerability to shocks, environment and other aspects (United Nations Development Programme, $2016)^{3}$. These indicators assess the inability to meet fundamental human needs. The discussion of how best to measure poverty is a matter related to ensuring consistency in the knowledge thereof (Greve, 2020, p. 10) $)^{4}$. In the main, poverty modifies people's behaviours by making them sensitive to minimum subsistence constraints and dependent on their society.

The crucial mission of the poverty reduction strategy is to act against inequalities of destiny and to allow real equality of opportunities. To achieve this end, states play predominantly on the social sectors and security. Investing in social sectors is a human rights approach in the fight against poverty, and consists in increasing the capacity of the State to ensure the basic social needs, namely, health, education, environment, habitat, etc. (Salmon, 2007, p.157) ${ }^{5}$. To face poverty through social investments, governments across the globe build collective infrastructure in the aforementioned areas and take other supporting measures to improve the quality of services offered. Thus, strengthening social security measures is another way by which governments strive to eradicate poverty. Social security is a set of public actions designed to reduce levels of vulnerability, risk, and deprivation and is an instrument for addressing inequality and vulnerability (Singh and Chudasama, 2020, p. 2) . Social security can also translate into free access to basic social services, mainly health, education and housing. Based on the social organisation, another construction of poverty indicators was established on national accounts 
and household living standards, as measured by consumption defined in a way that matches as far as possible household practices (World Bank, 2017) ${ }^{7}$. Therefore, social security enables public authorities to tackle poverty directly and effectively at the root, and for beneficiaries to have recourse to collective social services in addition to income in order to meet their crucial needs.

It appears that poverty resists strategies implemented over years in Low-Income Countries. Are excluded in this category, most of the European and North American countries as well as Australia, New Zealand and Japan (Nielsen, 2011, p. 20) ${ }^{8}$. Is part of Low-Income Countries, a country termed as a developing world country with a low Human Development Index (HDI) and a less developed industrial base located in African, South American and Asia (International Monetary Fund, 2019) ${ }^{9}$. Thus, in face of financial difficulties, Low-Income Countries struggle to end poverty through poverty reduction expenditures. Through this strategy, the government identifies the incidence, causes of poverty, and determines specific strategies and policies to reduce that, including expenditures targets (Elkins et al., 2015, p. 2) ${ }^{10}$. This is about increasing the income through family allowances to enable households to meet their basic needs.

In addition to the limitation of poverty reduction expenditures, scholars and organisations also established that a set of issues related to political economy is proving to be a challenge for poverty reduction. The national political economy refers to economic production and its relation with consumption and government. It also includes the distribution of wealth and national income in a country. It embraces issues related to industrialisation as well as economic diversification and growth of backward regions (List, 2018, p. 5) ${ }^{11}$. On this note, there has long been a set of literature and evidence suggesting that national political economy pillars referred to above are capable of increasing national incomes across the board and thereby addressing the poverty phenomenon effectively. Conversely, this literature and evidence also establish that the weakness of these political economy pillars forms the bottleneck that undermines poverty reduction strategies. In line with this debate, this paper reviews this literature and evidence suggesting the link between poverty and industrialisation as well as economic diversification and growth in Low-Income Countries.

\section{Research Method}

This study has been conducted based on the narrative review approach whose purpose is to identify a few studies that describe a specific problem of interest to provide additional analyses and highlight future directions. The narrative review is deemed the "traditional" way of reviewing the literature and evidence and is merely oriented towards a qualitative interpretation of prior knowledge (Sylvester et al., 2013) ${ }^{12}$. In the context of this study, it is a general review that assesses the most important and critical aspects of the current knowledge over the success and failure of poverty reduction with regard to aforementioned prominent political economy pillars, namely, industrialisation as well as economic diversification and growth in Low-Income Countries. The review of literature and evidence plays a critical role in scholarship because science always turns out to be a cumulative endeavour (Vom Brocke et al., 2015) ${ }^{13}$. Under these circumstances, this paper undertakes the task of reading thoroughly a few academic articles and organisations reports in order to demonstrate the value of their respective insights regarding the success and failure of poverty reduction strategy in Low-Income Countries and as such, it is secondary research.

The paper employs rigorous and explicit guidelines that highlight the coherence of analysis, the connection with theory, the missing point and the significance of the work or idea. In this way, the narrative review of literature and evidence is relevant in political and social sciences because it pulls many different pieces of information together and presents a broad perspective on a topic (Green et al., 2006) ${ }^{14}$. This approach helps assess ideas in a balanced way that highlights both negative and positive qualities concerning what is known and unknown. As for the sampling method of the study, apart from the fact that the sources of data should have been scholarly publications and trustworthy global development organisations, the random selection enabled impersonal choice rather than following pre-determined criteria. The impartiality of this approach allowed reviewing a growing body of literature and evidence investigating the links between poverty and the weakness of political economy pillars at a national level. Thus, reversing the circumstances alluded to above is central to the fight against poverty, which plagues developing countries as a whole.

\section{Poverty Reduction and Industrialisation}

The industrialisation process is the approach of manufacturing products in a production line by resorting to techniques that allow lower labour productivity. Influencing the lives of the people, industrialisation follows the application of science to the problems of economic production and consumption. The link between industrialisation and poverty has been the subject of Weiss $(2011)^{15}$ analysis in his research based on current trends in industrial development drawn on available statistics in developing countries. Weiss (Ibid, p. 4) observed between 2000 and 2005 a lower industrialisation described as annual growth of manufacturing or structural shifts in production in high-technology sector shares in GDP \% in selected countries in East Asia and Pacific (9.8\%), Latin America and the Caribbean (1.7\%), the Middle East and North Africa (6.4\%), South Asia 
$(7.0 \%)$ and Sub-Saharan Africa (2.6\%). He then linked weak industrialisation to poverty through average per capita income, which was US\$ 1,627 in East Asia and Pacific, US\$4,008 in Latin America, US\$2,241 in the Middle East and North Africa, US\$684 in South Asia and US\$745 in Sub-Saharan Africa (Ibid). He affirmed that industrialisation has a strong potential for dynamics of growth thought to be a path to poverty reduction, but this process has been very uneven because some parts of Low-Income Countries are largely non-industrial (Ibid). He found that its weakness does not favour the expansion of national income for government. He also argued that the lack of industrialisation in Low-Income countries impedes mass production that helps address the issue of public consumption and income. This work links suitably poverty reduction and industrialisation through government income collected from the production sector. However, there is no evidence showing that both situations influence negatively and equally poverty reduction. Alvarez et al. $(2015, \text { p. } 23)^{16}$ followed up on the arguments advanced here above and found that as its efforts have gone forward, industrialisation has had a more significant impact on poverty alleviation in at least some countries. In contrast, they contend that the lack of the industrialisation process does not favour economic progress, which is deemed a determining factor for poverty reduction strategy. The weakness of this study is that it just explains that this situation is frequently observed in Low-Income Countries where implementing industrialisation is not an easy affair. Therefore, this truncated view needs to be addressed by further research on this issue.

It is then taken for granted that the lack of industrialisation does not favour the fight against poverty, as this shortage and mass production are poles apart. Mass production tackles better the consumption issue while translating into national economic growth. In its report on regional integration, the African Development Bank $(2014 \text {, p. } 13)^{17}$ claimed that there is no dominant technological sector in African countries with more potential to support industrialisation, thereby reducing poverty. The Bank (Ibid, p. 29) relied on the New Partnership for Africa's Development model and found an insignificant growth in Foreign Direct Investment flows in the industrial sector (6\% per annum by 2012) in this continent. This low industrialisation is associated with a lower logistics performance index that describes the quality of trade and transport in relation to infrastructure and industrialisation ( 2.31 on a scale of 1 to 5 ). The Bank affirmed then that the industrialisation process has also the task of increasing the level of national production, which reverberates on poverty reduction through the income distribution (Ibid). This report has the merit of introducing new insights, which is that the lack of industrialisation does not allow for economies of scale because this industrialisation is associated with the same means of production. From that, it is taken as a fact that a company may not be able to produce more to satisfy a large number of people. However, this study does not show whether this situation is widely observed in LowIncome Countries and whether it affects these countries' ability to promote poverty reduction strategy in the same way. Correa and Kanatsouli $(2018)^{18}$ also explored the link between industrialisation and poverty between 1996 and 2016 in the least developed countries selected in Africa and Asia by calculating their Economic Vulnerability Index (49.2, 47.4, 53.4, 50.6, 45.7 and 41.4 respectively in 2000, 2003, 2006, 2012 and 2015). This index measures a country risk of being harmed by economic shocks. They used the Manufacturing Value Added (MVA) per capita set out by the United Nations Industrial Development Organisation and the Human Assets Index (HAI) provided by the United Nations Committee for Development Policy. The first index, which was $15.1,11.8,11.5,11.4,11.5$ and 12 respectively in 1990, 1995, 2000, 2005, 2010 and 2016, is a relative value of net manufacturing output to the population size, to assess a country's level of industrialisation. The second one, which was 40.9, 39.6, 43.6, 45.8, 45.2 and 51.5 respectively in 2000, 2003, 2006, 2009, 2012 and 2015, is a composite index used as an identification criterion for Least Developed Countries (LDCS) and includes education and health. For the full sample, they found that sharped by the manufacturing sector, industrialisation has significant advantages and therefore any structural change that promotes that sector is expected to foster economic growth and raise the general well-being (Ibid, p. 26). For digging out the contribution of industrialisation, Correa and Kanatsouli's study suggests that its weakness does not allow production units to increase their performance and profit. This approach is relevant because it clarifies that this situation affects the country's income level that boosts its ability to fund social activities deemed essential to fighting poverty.

Industrialisation being a long-term process that seeks to reverse production techniques, it must go through total control of new technical norms or standards to obtain products of high quality and in large quantities. That is why based on a world input-output table (1995-2011) applied on China, Brazil, Indonesia, Mexico and Turkey, the International Monetary Fund (2016) ${ }^{19}$ analysed how industrialisation affects poverty through the value-added consumption. The IMF captured this reflection on the Lorenz Curve and the Gini coefficient, which showed 0.57/0.60 in Brazil, 0.59/0.65 in China, 0.63/0.67 in Indonesia, 0.68/0.71 in Mexico, 0.58/0.63 in India and $0.56 / 0.64$ in Turkey (Ibid, p. 19). The IMF found out that this step must involve a variety of stakeholders, namely the government. The latter has the heavy mission of putting into practice all new production methods and techniques designed during the planning phase. This report is exhaustive because, in addition to the benefits of industrialisation, it explains that this process strives to replace the artisanal or manual production system in production sites scattered across the country, with increasingly sophisticated techniques, tools and machines for 
mass production. Furthermore, it also explains how it affects the mass production that favours income increase, thereby poverty reduction strategy. More importantly, the International Monetary Fund (Ibid) argued that an industrialised economy has easy access to world markets, which is also a necessary condition for sustained economic growth and poverty reduction. In that vein, industrialisation is described here as the shift from a system using rudimentary techniques and equipment to one that is more specialised and has the consequence of radically changing the way of life in a given country. However, while contending that industrialisation affects poverty through growth, the report remains silent on whether this economic growth depends solely on this industrialisation.

Industrialisation process seeks above all to replace a rudimentary production system and by extension, to promote the general economic and social conditions in the country. Considering this approach, Yulek (2018) ${ }^{20}$ employed the sequence science-technology-innovation-development to investigate industrialisation-poverty reduction nexus and argued that the lack of industrialisation observed in Low-Income Countries does not favour a production system characterised by the use of modern production tools. His findings suggest that industrialisation alone explains why developing countries are poor and how it can break out of Low and MiddleIncome Traps. Public authorities foster this process in symbiosis with the private sector, in order to increase their market shares and promote socio-economic development. Compared to the primary sector, manufacturing is the pinnacle of any meaningful and sustainable development and so industrialisation plays a crucial role in promoting social inclusiveness (Ibid). Therefore, he established that developing countries are not embarked on this demanding process. The point is that Yulek just explored the consequences of weak industrialisation on poverty without suggesting efficient ways of solving this situation. Therefore, a complementary study towards this direction could help advance knowledge on the link between industrialisation and poverty reduction.

\section{Poverty Reduction and Economic Diversification}

Economic diversification is the process of moving an economy from a single source of income to multiple ones from a wide range of both economic sectors and markets. In this respect and based on 2013 data, Freire $(2017)^{21}$ simulated in 30 developing countries the model of structural economic dynamics and endogenous technological change that could replicate empirical regularities linking economic diversification and poverty. He used a logarithm associating economic diversification with employment, wage and consumption per capita. He concluded that a lower diversification drove a lower labour coefficient of 0.5 , lower coefficient of consumption per capita of 0.01 and lower wage rate, which all led to the lower average income per capita, less than $\$ 1$ per day, thereby to poverty (Ibid, p. 19). His finding affirms that economic diversification is applied as a strategy to encourage positive economic and social development. The reason is that it is recognised in key internationally agreed development goals that economic diversification is relevant for developing countries, and in particular, the least developed ones since it fosters structural transformation and social development (Ibid:2). Moreover, he explained that this approach gained momentum with the negative economic evolution of developing countries, and therefore these countries do not capitalise on this policy (Ibid). While supporting that this policy is lacking in these countries, Freire does not indicate the role of the extension of the globalisation of economies. However, his contribution is that the governance theory highlighting the role of public authorities in development advocate economic diversification as a determining factor in combatting poverty. In a seminal empirical study using the cross-sectoral rebalancing of output approach scaled from zero to one, the World Bank $(2019)^{22}$ assessed the impact of economic diversification on poverty between 1991 and 2018 in Sub-Saharan Africa, Latin America and the Caribbean, Middle East and North Africa and East Asia Pacific. This World Bank study shows that from 1991 to 2018, agriculture moved from 65 to $75 \%$ of GDP, construction from 7 to $9 \%$, manufacturing from 11 to $12 \%$, mining from 2 to $3 \%$, and services from 14 to $17 \%$ of GDP (Ibid:135-140). The study suggests a low Export-Diversification-Poverty indicator of these countries reported to be less than 0.5 and thereby affirming that economic diversification is a key element of economic development and fight against poverty in which a country moves to a more diverse production and trade (Ibid). The strong point of this study is that it evidences how a weak economic diversification in Low-Income Countries has impeded poverty reduction strategy by subverting the increase in Gross Domestic Product and the balanced development of all economic sectors. Although this might be correct, more has to be done to understand whether this approach secures an equal economic integration of all regions of the country.

It is regarded as likely that a weak economic diversification undermines a poverty reduction strategy in that the increase of Gross Domestic Product is unlikely to happen. Indeed, economic diversification in a country always leads to an increase in national wealth in that country. The paper of Hare $(2011, \text { p. } 20)^{23}$ concurs with the above in the sense that influential on GDP growth, the economic diversification has become fashionable to focus development efforts and so it is generally the most effective way of reducing poverty. Furthermore, Hare indicated that as observed in the large section of Low-Income Countries, this does not occur, because apart from flagship industries, all economic sectors are neglected (Ibid). The above approach is not satisfactory. The reason is that Hare does not indicate whether a weak economic diversification always results in stagnation or a drop in 
national production. He just explained that weak industrialisation undermines government and households' income deemed the main factor that helps contribute to poverty reduction. On his side, Olander $(2019 \text {, p. 351 })^{24}$ used the approach to economic diversification function as a constraint for social development in selected countries across the globe between 1993 and 2018. His empirical test showed a correlation between economic diversification where it was $.019, .008, .020, .007$ and .022 , and the corresponding GDP in capita, which was $.027, .005, .031, .003, .021$ and .005 (Ibid, p. 357). He concluded that Low-Income Countries suffer from poverty due to a lack of economic diversification because when the economy is concentrated to a few sectors rather than more diverse, it could not lead to its improvement needed to spur a desired economic growth. The latter lifts millions out of poverty and wretched living conditions. The positive point of this study is its assertion that this negative impact is observed in all economic sectors, considering that these are not part of the strategy of economic diversification.

A weak economic diversification does not argue in favour of poverty reduction, as this shortage does not lead to a balanced development of all economic sectors. Bearing in mind this paradigm, the Asian Development Bank (2019) ${ }^{25}$ analysed disparities in diversification across Asia based on the Herfindahl-Hirschman concentration indexes (HHCI), which is a commonly accepted measure of market concentration that measures the size of companies in relation to the industry and the amount of competition among them. The Bank demonstrated that between 1995 and 2000, economic diversification inevitably leads to a balanced development of all categories of products and services in a country (Ibid). Apart from India, South Korea and Thailand whose Herfindahl-Hirschman concentration indexes was respectively 0.1, 0.2 and 0.1, the remaining 39 Asian countries had moderately diversified export portfolios and were so highly concentrated (Ibid:9). This trend could not boost economic growth and strengthen poverty reduction (Ibid). Seen as a strong catalyst, the economic diversification index of less than 0.5 was observed in Central, East, South and Southeast Asia as these sub-regions often struggled to diversify so that these cannot address poverty among vulnerable groups for more inclusive development (Ibid). This report establishes clearly that as observed in developing countries, taking into account the fact that not all economic sectors benefit from the same attention in the context of the diversification policy, they are characterised almost automatically by the less proportional increase. Similarly, as he exploited the demand-led related diversification (DLRD) model that asserts that an increase in aggregate demand ultimately causes an increase in total output, Mahroum and Al-Saleh $(2018)^{26}$ established unequivocally that developed countries take a special interest in the economic diversification. Therefore, this approach forms a major driver of their economies and subsequently is a significant contributor to government revenues to address welfare and poverty issues. In contrast, his findings show that in African countries and the Caribbean described as singleindustry regions centred on natural resources, a weak economic diversification affects economic sectors as these sectors suffer from lack of attention (Ibid). The positive point of this study is that the significance of this impact on poverty reduction strategy is well obvious because it is remarkable. It is worth saying that in those countries where the economic diversification has been successful, the public authorities have beside reduced their economic dependence on a single industry. However, the study merely overlooks the ability of economic diversification to cushion the economic shock resulting from this single industry, and this gap offers opportunities for further complementary research.

A weak economic diversification does not support a comprehensive approach to poverty reduction since this situation does not foster the economic integration of all regions of a country. This situation is observed frequently in Low-Income Countries. The above-mentioned fact has been evidenced by Ali and Cantner (2020) ${ }^{27}$ research in the least developed countries in Europe between 1996 and 2010 based on three types of diversification indices (related, unrelated and overall diversification). Indeed, in all countries that have not embarked on economic diversification, there has not been easy integration of all regions that make up that country. Economic diversification is recognised as a strong determinant of human development in developing countries because its high level improves social welfare by providing a wide range of alternatives to the economic agents (Ibid). This situation results from the fact that the different regions of a country are not involved in the same way in economic diversification. The problem here is that Ali and Canter do not indicate if it is easy to detect various opportunities for trade between regions in a country because they do not produce the same products. However, this paper suitably highlights that economic diversification is one of the best strategies for development economics that help fight poverty. Consequently, its importance and its effects are noticeable. Using a pattern of economic diversification that comprises the export concentration index, the World Trade Organisation et al., (2019) ${ }^{28}$ found an average export diversification index less than 0.5 in 85 developing countries between 2006 and 2017. The export concentration index measures the degree of market concentration in a country. It determines whether a large share of commodity exports are accounted for by a limited number of countries or, on the contrary, if exports are distributed evenly among a number of countries. This index was calculated and oscillated between 0.3 and 0.5 on a scale of 0.0 and 1.0 , where 0.0 indicates the high degree of economic concentration (Ibid, p. 19). Through the mechanism of facilitator, this index affected GDP per capita (oscillating between $\$ 1500$ and $\$ 1700$ ), which reverberated on the human 
development index (oscillating between 0.6 and 0.8) (Ibid, p. 5). This coherence suggests that a weak economic diversification in developing countries contributes to the stagnation of incomes and the lack of improvement of human development. The World Trade Organisation determined that progress in some countries has inevitably brought substantive income seen as a fundamental element conducive to extreme poverty reduction (Ibid, p. 31). By contrast, the lack of economic diversification does not allow Low-Income countries to advance commendable poverty reduction strategies (Ibid). The main criticism of this view is its narrow perspective in the sense that it only focuses on economic diversification and thereby concludes that Low-Income countries could not at all address social issues that form poverty indicators.

\section{Poverty Reduction and Economic Growth}

Economic growth is described as an increase in the quantity of internal production in a region, a country, a continent or worldwide. It manifests itself in a lasting and significant increase in the production of goods and services, which reverberate on government and households' income. In their paper assessing the causality between economic growth and world poverty worldwide, Rahim et al. $(2014, \text { p. } 12)^{29}$ reaffirmed that economic growth is a determining factor involved in the fight against poverty. Their study relied upon various World Bank and United Nations Development Programme reports suggesting that with an average economic growth of less than $5 \%$, the incidence of poverty did not decline since the $1990 \mathrm{~s}$ in the least developed countries. By contrast, the success of the Asian tigers following a significant economic growth that affected the income distributions of their people had been responsible for the vast improvement in the alleviation of poverty in these countries. They then concluded that through mainly the income generation mechanism that depends on economic growth, poverty reduction becomes the ultimate aim of development endeavours towards a more prosperous and accountable world. The accuracy of Rahim's et al. view on poverty rests on the well-known theory that the economic policy helps understand the linkage between this macroeconomic aggregate and poverty reduction strategy. This approach meets remarkably the studies reviewed below, which suggest that commendable economic growth has a positive and lasting impact on purchasing power and living standard, which reverses the economic-related poverty in a country. Therefore, weak economic growth has the opposite effect. As shown in a sample of 18-selected Latin America and Caribbean countries from 1981 to 2012, Zama and Shamsuddin $(2018)^{30}$ proposed a new measure of pro-poor growth index called 'Poverty Interdependence Growth Index (PIGI)'. The latter was further extended to satisfy the monotonicity criterion of pro-poor growth and poverty reduction, termed 'Poverty Interdependence Equivalent Growth Rate (PIEGR)'. Based solely on the education and health data, the estimates of PIGI and PIEGR revealed that out of 18 countries, 11 countries showed a negative pro-poor growth index, 3 countries showed pro-rich, and 4 countries showed highly pro-poor growth. The above suggests that the impact of growth-related per capita income on poverty is 'linear' when controlling the non-linear components of growth. However, without this assumption, the 'U-shaped' and/or 'asymptotic' relationship is not established. The contribution of this study to the debate on poverty reduction is how new measures of pro-poor growth index support conclusive findings. However, this study has a limited scope since it is centred merely on educational and health expenditures and overlooks other poverty indicators.

Weak economic growth in any geographical entity, while its population is assumed to be on the rise, turns back the purchasing power. Following the above reasoning, Kakwani and Hwa Son (2018) ${ }^{31}$ used a crosscountry regression model to analyse the relationship between economic growth and poverty reduction strategy. This model helped assemble large samples of data from a group of developing countries, all at various development stages, and then statistically calculated whether economic growth has had a notable impact on poverty reduction. Their finding is that since economic growth means an increase in national income, it results in a better and improved understanding of its linkage with poverty reduction, which is also measured in terms of revenue. The above indicates that one of the inevitable effects of economic growth is the increase of purchasing power. Kakwani and Hwa's work underlines that economic growth always results from the increase in production, which results in the payment of production factors such as labour (Ibid). That is why this growth has as a corollary the rise in purchasing power (Ibid). Essentially, this study clarifies suitably the economic growth influence on households' income, thereby on poverty, through the decline in unemployment. Indeed, healthy economic growth in a country is characterised by a drastic decrease in unemployment capable of overturning poverty. However, relying on Gini coefficients of income inequality, the Organisation for Economic Cooperation and Development $(2014)^{32}$ established that like in Greece and Turkey, the least developed countries in the OECD area with a Gini less than 0.29 , the situation described above is not observed in developing countries. Called also Gini index or Gini ratio, the Gini coefficient is a measure of statistical dispersion that aims to represent the wealth or income inequality within a nation or a group of people. This research evidences that poverty matters for growth. Hence, policymakers have to address the trade-off between promoting growth and tackling inequality. The reason is that limited economic growth impedes poverty significantly, and this shortage triggers an increase in unemployment that reverberates negatively on people's income (Ibid:3). As developed above, the finding of the OECD study is relevant because it ascertains that this link is direct, especially since a human being is a 
production factor in the same way as the land or working tools such as machines, equipment.

The forgoing affirms that a weak economic growth undermines the income distribution of production factors, which enable an economy to work as appropriate in the long term. Referring to the above theoretic framework and based on the Kuznets inverse-U relationship, McKnight (2019) ${ }^{33}$ critically analysed the causal mechanism of the poverty-growth-inequality triangle hypothesis in the least well-off countries. The Kuznets' inverted-U hypothesis suggests that economic growth drives income inequality first and addresses it later at a higher stage of economic development. McKnight hypothesised an existing but non-linear relationship between economic growth and poverty. He found that the income distribution is an instrument of poverty reduction premised on the theory that where it is from economic growth and shared equally among all, it does lead to a proportional decrease in relative poverty level. Based on this reasoning, McKnight argued that conversely, the limited economic growth decrease the living standard, and this situation is widespread in LowIncome Countries. Similarly, Fauzel $(2020)^{34}$ contended that economic growth is relevant in the attempt to alleviate poverty. Based on the vector error-correction model established as a dynamic econometric technique, he conducted a quantitative investigation and assessed the impact of trade on poverty reduction in Mauritius between 1990 and 2017. She suggested an export-led poverty reduction strategy because this approach could help integrate poor communities into economic growth through trade. McKnight and Fauzel's governing idea is that economic growth translates into a substantial improvement in the general living standard of people. This improvement is all the more likely in the event that this growth can be described as distributive. However, their view does not confirm that the population in its great majority benefits from the collateral effects of the economic growth generated by all economic sectors of a country. This missing point opens the door to further research for this clarification. The link between poverty reduction and economic growth was also at the epicentre of the Gupta's $(2020)^{35}$ work carried out in India. They found that based on the rise of labour productivity, which was 3.2\% between 1999 and 2004/05, and 8.1\% between 2004/05 and 2011/12, the annual growth in poverty reduction also increase proportionally, driven by the dynamic reallocation effect (Ibid). Thus, in contrast to the decades before when the level of poverty rose drastically in this country, economic growth since the mid1990s has had a significant and broad impact on living conditions (Ibid). That is because this growth drove a five-fold rise in per capita income to $\$ 1,500$ per annum by 2015 , which transited this country to a middle-income one (Ibid). The strength of this study is its use of a multidimensional poverty index. As this index covers all the components of poverty, the study gave the overall picture of poverty measurement. However, similar studies should be conducted in other countries with different circumstances to see whether they will lead to similar findings.

The preceding illustrates that steady economic growth has beneficial effects on poverty reduction strategy, whereas the contrary undermines this strategy in Low-Income Countries. On this note, Maki et al. $(2015)^{36}$ conducted a multifaceted study on economic growth and poverty by applying Engel's law in the Philippines as well as analysing the impact of the informal economy in Indonesia, growth-related expenditure in Sri Lanka and growth-related employment in Thailand. In the Philippines, the effects of in-kind consumption assumed to be dependent on the stage of economic growth were relevant in terms of improving the living standard of poor households (Ibid, p. 5). In Indonesia, the economic growth resulting from the boom of the informal economy reverberated in an average of $25 \%$ job increase that affects poverty by $20 \%$ (Ibid). In Sri Lanka, notwithstanding the civil war, the broader context of economic growth between 2006 and 2010 moved the unemployment by 4.9, which led the poverty headcount index declined from $15.2 \%$ to $8.9 \%$ (Ibid:7). In Thailand, the country rapid economic growth between 2006 and 2012 boosted employment by 39.6\%, which resulted in the decrease of poverty by $30 \%$ (Ibid, p. 7). He concluded that developing countries experience many problems stemming from inequality and poverty whose the coefficient increases as the economic growth decreases (Ibid, p, 1). According to Maki, it is then clear that economic growth turns out to be an essential component for the best perspective of development economics. The above is achieved thanks to its numerous beneficial effects on the population and macroeconomics aggregates of that country. The outstanding contribution of Maki to this debate is that he identifies the big challenge, which is that this economic growth has to be both sustainable and generalised to be effective in reducing the poverty rate in the country in which this growth has taken place. The United Nations Development Programme (2016) ${ }^{37}$ corroborated the above view with the advent of the World Sustainable Development Goals. Indeed, this United Nations agency established that with the economic growth, there are always grounds for optimism on improving social equity simultaneously (Ibid, p. 7). Therefore, making the most of this momentum helps reverse growing inequalities and eradicate extreme poverty (Ibid). Both studies have the merit of clarifying that this poverty reduction strategy operates through the income redistribution mechanism triggered by a country production system and the public authorities through various family allowances. Consequently, these incomes allow households to spend for their basic social needs, and this general trend is conducive to poverty reduction. 


\section{Conclusion}

This study aimed to survey the link between poverty reduction and industrialisation as well as economic diversification and growth in the context of Low-Income Countries. To achieve this mission, the study employed the narrative review approach. It, therefore, scrutinised wide-ranging literature and evidence from scholarly and organisations publications. As to the findings, the studies reviewed by this paper share single merit. Indeed, these studies suggest that weak industrialisation, as well as low economic diversification and growth, are proving to exercise a negative impact on poverty reduction in developing countries as a whole. This fact is also corroborated by evidence that the overwhelming majority of people in developing countries are still living under the poverty line established as the crucial poverty indicator by specialised organisations, namely, the United Nations Development Programme and the World Bank. The above is thus the strong point of all publications reviewed by this paper.

The main criticism over the literature and evidence reviewed herein stems from their overreliance on the assumption that income is the unique drive of poverty reduction. The above approach is mono-causal and, therefore, somewhat short in ambition. Indeed, all of them explain the link between poverty reduction and the political economy pillars referred to above through revenue and employment established as unique transmission channels. Everything has been left out of the debate. Consequently, overlooking other explanatory factors is a limitation because implementing optimal poverty reduction strategies in a socially and economically demanding environment of Low-Income Countries should involve a multidisciplinary approach. Therefore, this gap opens the door for further research on the topic. The widespread failure of poverty reduction in these countries needs to be clarified for appropriate response. Hence, these studies on their own give a restrained conclusive explanation. Thus, other explanatory factors upstream and downstream require more attention. Overall, the underlying shortcomings of the political economy strategies alluded to above are conducive to adverse effects on poverty reduction. The reason is that these translate systematically into the inability of these countries to generate substantial revenue through the increase in the Gross Domestic Product, the balanced growth of all economic sectors, and the economic integration of their regions. The weakness of the literature and evidence on poverty reduction reviewed in this article suggests that future research could consider particular circumstances of countries such as natural resources endowment, societal values and the form of governance. Indeed, rather than relying solely on the income aspect of industrialisation, economic diversification and growth, integrating the circumstances alluded to above in the analysis could help nuance the success and failure of poverty reduction. This approach helps avoid putting all the countries subject to research on an equal footing.

\begin{tabular}{|c|c|c|c|c|}
\hline Author(S) & Period & Countries & Method & Main Findings \\
\hline Weiss (2011) & $2000-2005$ & $\begin{array}{ll}\text { - } & \text { East Asia/ Pacific } \\
\text { - } & \text { Latin America and } \\
\text { the Caribbean } \\
\text { - } \quad \text { Middle East and } \\
\text { North Africa } \\
\text { - } \quad \text { Sub-Saharan Africa }\end{array}$ & $\begin{array}{l}\text { Shifts in High- } \\
\text { technology in GDP \% }\end{array}$ & $\begin{array}{l}\text { Weak industrialisation } \\
\text { in these regions impeded } \\
\text { mass production, } \\
\text { national income, and } \\
\text { this did not favour } \\
\text { poverty reduction. }\end{array}$ \\
\hline $\begin{array}{l}\text { Alvarez et } \\
\text { al. (2015) }\end{array}$ & Unspecified & Global South & $\begin{array}{l}\text { Industrialisation- } \\
\text { economic progress } \\
\text { approach }\end{array}$ & $\begin{array}{l}\text { Negative impact of } \\
\text { weak industrialisation } \\
\text { on economic progress, } \\
\text { national income and } \\
\text { poverty reduction. }\end{array}$ \\
\hline $\begin{array}{l}\text { African } \\
\text { Development } \\
\text { Bank (2014) }\end{array}$ & $2010-2013$ & Africa & $\begin{array}{l}\text { New Partnership for } \\
\text { Africa Development } \\
\text { Model }\end{array}$ & $\begin{array}{l}\text { Insignificant Foreign } \\
\text { Direct Investment in } \\
\text { industrialisation drove } \\
\text { lower national } \\
\text { production that } \\
\text { reverberated negatively } \\
\text { on national income and } \\
\text { poverty reduction. }\end{array}$ \\
\hline $\begin{array}{l}\text { Correa and } \\
\text { Kanatsouli } \\
(2018)\end{array}$ & $1996-2016$ & $\begin{array}{ll}\text { - } & \text { Africa } \\
\text { - } & \text { Asia }\end{array}$ & $\begin{array}{l}\text { Manufacturing Value } \\
\text { Added per capita and } \\
\text { Human Assets Index }\end{array}$ & $\begin{array}{l}\text { Lack of structural } \\
\text { changes } \\
\text { industrialisation could } \\
\text { not foster economic } \\
\text { growth, national income } \\
\text { and general well-being. }\end{array}$ \\
\hline
\end{tabular}


Table 1. Summary of Literature and Evidence on Poverty Reduction and Industrialisation

\begin{tabular}{|l|c|c|l|l|}
\hline \multicolumn{1}{|c|}{ Author(S) } & Period & \multicolumn{1}{c|}{ Countries } & \multicolumn{1}{c|}{ Method } & \multicolumn{1}{c|}{ Main Findings } \\
\hline $\begin{array}{l}\text { International } \\
\text { Monetary } \\
\text { Fund (2016) }\end{array}$ & $1995-2011$ & $\begin{array}{l}\text { Brazil } \\
\text { - China } \\
\text { - Indonesia }\end{array}$ & $\begin{array}{l}\text { Industrialisation } \\
\text { effect through value- } \\
\text { added consumption } \\
\text { and Gini Coefficient }\end{array}$ & $\begin{array}{l}\text { Industrialisation affected } \\
\text { mass production, } \\
\text { income level, thereby } \\
\text { poverty reduction. }\end{array}$ \\
\hline Yulek (2018) & Unspecified & Global South & $\begin{array}{l}\text { Sequence science- } \\
\text { technology- } \\
\text { innovation- } \\
\text { development }\end{array}$ & $\begin{array}{l}\text { Weak industrialisation } \\
\text { could not break out of } \\
\text { low-income traps and } \\
\text { poverty. }\end{array}$ \\
\hline
\end{tabular}

\begin{tabular}{|c|c|c|c|c|}
\hline Author(S) & Period & Countries & Method & Main Findings \\
\hline Freire (2017) & 2011-2014 & 30 Developing Countries & $\begin{array}{l}\text { Structural } \\
\text { economic } \\
\text { dynamics and } \\
\text { endogenous } \\
\text { poverty }\end{array}$ & $\begin{array}{l}\text { Lower diversification drove } \\
\text { lower labour coefficient, } \\
\text { lower wage rate, lower } \\
\text { income and lower } \\
\text { consumption that induced } \\
\text { poverty. }\end{array}$ \\
\hline World Bank & 1991-2018 & $\begin{array}{ll}\text { - } & \text { Africa } \\
\text { - } & \text { Latin America } \\
\text { - } & \text { The Caribbean } \\
\text { - } & \text { Middle East }\end{array}$ & $\begin{array}{l}\text { Cross-sectoral } \\
\text { rebalancing of } \\
\text { output } \\
\text { approach }\end{array}$ & $\begin{array}{l}\text { Low Export-Diversification- } \\
\text { Poverty Indicator in these } \\
\text { regions. }\end{array}$ \\
\hline Hare (2011) & Unspecified & Global South & $\begin{array}{l}\text { GDP-Income- } \\
\text { Poverty model }\end{array}$ & $\begin{array}{l}\text { Weak economic } \\
\text { diversification drove the fall } \\
\text { in GDP, national income } \\
\text { and the rise of poverty. }\end{array}$ \\
\hline Olander (2019) & $1993-2018$ & Global South & $\begin{array}{l}\text { Economic } \\
\text { diversification } \\
\text { function as a } \\
\text { constraint for } \\
\text { poverty }\end{array}$ & \begin{tabular}{llr} 
Correlation & \multicolumn{2}{r}{ between } \\
economic & diversification \\
and GDP per capita, \\
national income and \\
poverty.
\end{tabular} \\
\hline $\begin{array}{l}\text { Asian } \\
\text { Development } \\
\text { Bank (2019) }\end{array}$ & $1995-2000$ & $\begin{array}{ll}\text { - } & \text { Central Asia } \\
\text { - } & \text { East Asia } \\
\text { - } & \text { South Asia } \\
\text { - } & \text { Southeast Asia } \\
\end{array}$ & $\begin{array}{l}\text { Herfindahl- } \\
\text { Hirschman } \\
\text { concentration } \\
\text { index } \\
\end{array}$ & $\begin{array}{l}\text { Lower } \\
\text { diversification could not } \\
\text { boost GDP, national income } \\
\text { and poverty reduction. }\end{array}$ \\
\hline $\begin{array}{l}\text { Mahroum and Al- } \\
\text { Saleh (2018) }\end{array}$ & Unspecified & Global South & $\begin{array}{l}\text { Demand-led } \\
\text { related } \\
\text { diversification }\end{array}$ & $\begin{array}{l}\text { Economic diversification } \\
\text { drove national revenue that } \\
\text { tackled poverty reduction. }\end{array}$ \\
\hline $\begin{array}{l}\text { Ali and Cantner } \\
(2020)\end{array}$ & $1996-2010$ & $\begin{array}{l}\text { Least developed countries } \\
\text { in Europe }\end{array}$ & $\begin{array}{l}\text { Related- } \\
\text { unrelated- } \\
\text { overall } \\
\text { diversification }\end{array}$ & 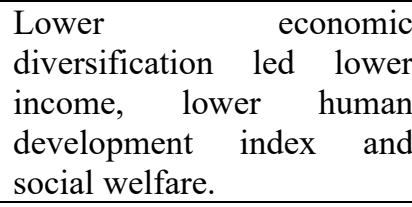 \\
\hline $\begin{array}{l}\text { World Trade } \\
\text { Organisation et } \\
\text { al. (2019) }\end{array}$ & $2006-2017$ & World & $\begin{array}{l}\text { Export } \\
\text { Concentration } \\
\text { Index }\end{array}$ & $\begin{array}{l}\text { Weak economic } \\
\text { diversification contributed } \\
\text { to the income stagnation and } \\
\text { lower human development } \\
\text { index. }\end{array}$ \\
\hline
\end{tabular}




\begin{tabular}{|c|c|c|c|c|}
\hline Author(S) & Period & Countries & Method & Main Findings \\
\hline$\underset{(2014)}{\operatorname{Rahim}} \quad$ et $\quad$ al. & Unspecified & Global South & $\begin{array}{l}\text { Growth-income- } \\
\text { poverty } \\
\text { reduction } \\
\text { expenditures }\end{array}$ & $\begin{array}{l}\text { Economic } \\
\text { generated income } \\
\text { reduced poverty. }\end{array}$ \\
\hline $\begin{array}{l}\text { Zama and } \\
\text { Shamsuddin } \\
(2018)\end{array}$ & $1981-2012$ & $\begin{array}{l}18 \text { Selected Latin } \\
\text { American and Caribbean } \\
\text { countries }\end{array}$ & $\begin{array}{l}\text { Poverty } \\
\text { Interdependence } \\
\text { Growth Index } \\
\text { and Equivalent } \\
\text { Growth Rate }\end{array}$ & $\begin{array}{l}\text { The impact of growth- } \\
\text { related per capita income } \\
\text { on poverty was 'linear' } \\
\text { when controlling the non- } \\
\text { linear components of } \\
\text { growth. }\end{array}$ \\
\hline $\begin{array}{l}\text { Kakwwani and } \\
\text { Hwa Son (2018) }\end{array}$ & Unspecified & $\begin{array}{l}\text { Selected developing } \\
\text { countries in Africa, Asia } \\
\text { and Latin America }\end{array}$ & $\begin{array}{l}\text { Cross-country } \\
\text { regression } \\
\text { model }\end{array}$ & $\begin{array}{l}\text { Economic growth boosted } \\
\text { national income, which } \\
\text { resulted to poverty } \\
\text { reduction measured in } \\
\text { terms of revenue. }\end{array}$ \\
\hline OECD (2014) & $1980-2011$ & $\begin{array}{l}\text { Greece and } \begin{array}{r}\text { Turkey } \\
\text { developed }\end{array} \\
\text { Least } \\
\text { countries in the OECD } \\
\text { area) }\end{array}$ & $\begin{array}{l}\text { Gini coefficients } \\
\text { of income } \\
\text { inequality }\end{array}$ & $\begin{array}{l}\text { A rise of Gini coefficients } \\
\text { of income inequality was } \\
\text { accompanied with the rise } \\
\text { of poverty. }\end{array}$ \\
\hline McKnight (2019) & $1995-2015$ & $\begin{array}{l}\text { Sample of least well-off } \\
\text { countries in Africa, Asia } \\
\text { and Latin America }\end{array}$ & $\begin{array}{l}\text { Poverty-growth- } \\
\text { inequality } \\
\text { triangle } \\
\text { Hypothesis }\end{array}$ & $\begin{array}{l}\text { Limited economic growth } \\
\text { impeded poverty reduction } \\
\text { due to fall in income } \\
\text { distribution. }\end{array}$ \\
\hline Fauzel (2020) & $1990-2017$ & Mauritius Island & $\begin{array}{l}\text { Vector error } \\
\text { correction model }\end{array}$ & $\begin{array}{l}\text { Economic growth impacted } \\
\text { on poverty reduction } \\
\text { through export-led trade }\end{array}$ \\
\hline Gupta (2020) & $2004-2012$ & India & $\begin{array}{l}\text { Static and } \\
\text { dynamic } \\
\text { reallocation } \\
\text { effect }\end{array}$ & $\begin{array}{l}\text { Economic } \\
\text { alleviated poverty through } \\
\text { labour productivity growth }\end{array}$ \\
\hline $\begin{array}{l}\text { Maki } \\
(2015)\end{array} \quad$ et $\quad$ al. & $2006-2010$ & $\begin{array}{ll}\text { - } & \text { Philippines } \\
\text { - } & \text { Indonesia } \\
\text { - } & \text { Thailand } \\
\text { - } & \text { Sri Lanka } \\
\end{array}$ & Engel's Law & $\begin{array}{l}\text { Economic growth turned } \\
\text { out to be essential for } \\
\text { poverty reduction through } \\
\text { revenue distribution. }\end{array}$ \\
\hline $\begin{array}{l}\text { United Nations } \\
\text { development } \\
\text { Programme } \\
(2016)\end{array}$ & Unspecified & Global South & $\begin{array}{l}\text { World } \\
\text { Sustainable } \\
\text { Development } \\
\text { Goals }\end{array}$ & $\begin{array}{l}\text { Economic growth improved } \\
\text { social equity through } \\
\text { income distribution. }\end{array}$ \\
\hline
\end{tabular}

\section{References}

${ }^{1}$ Ravallion, M. (2003) The Debate on globalisation, poverty and inequality: why measurement matters. Policy Research Working Paper 3038, World Bank Development Research Group. World Bank: Washington, D.C. https://openknowledge.worldbank.org/handle/10986/18207

${ }^{2}$ Banerjee, A. et al. (2006). Understanding poverty. New York: Oxford University Press

${ }^{3}$ United Nations Development Programme (2016). The concept and measurement of poverty. New York: UNDP

${ }^{4}$ Greve, B. (2020). Poverty: the Basics. New York: Routledge

${ }^{5}$ Salmon, E. (2007). The long road in the fight against poverty and its promising encounter with human rights. International Journal of Human Rights, 4(7), 150-165 https://doi.org/10.1590/S1806-64452007000200007

${ }^{6}$ Singh, P. and Chudasama, H. (2020). Evaluating poverty alleviation strategies in a developing country, Journal of Economic Studies, 15(1), 1-23. doi.org/10.1371/journal.pone.0227176

${ }^{7}$ World Bank (2017). Monitoring global poverty report of the Commission on Global Poverty. Washington, D.C.: World Bank. https://openknowledge.worldbank.org/handle/10986/25141

${ }^{8}$ Nielsen, L. (2011). Classifications of countries based on their level of development: How it is done and how it could be done. Washington, D.C.: IMF. https://www.imf.org/external/pubs/ft/wp/2011/wp1131.pdf

${ }^{9}$ International Monetary Fund (2018). Macroeconomic developments and prospects in Low-income Developing 


\section{Countries. Washington, D.C.: IMF. https://www.imf.org/en/Publications/Policy-} Papers/Issues/2018/03/22/pp021518macroeconomic-developments-and-prospects-in-lidcs

${ }^{10}$ Elkins, M. et al. (2015). Do Poverty Reduction Strategy Papers reduce poverty and improve well-being? Discussion Papers in Economics No. 15/02. The University of Nottingham. https://www.nottingham.ac.uk/economics/documents/discussion-papers/sdp15-02.pdf

${ }^{11}$ List, F. (2018). National system of political economy. New York: Routledge

${ }^{12}$ Sylvester, A. et al. (2013). Beyond synthesis: re-presenting heterogeneous research literature. Journal of Behaviour and Information Technology, 32(12), 1199-1215. DOI:10.1080/0144929X.2011.624633

${ }^{13}$ Vom Brocke et al. (2015). Standing on the shoulders of giants: Challenges and recommendations of literature search in Information Systems research. Communications of the Association for Information Systems, 37(1), 205-224. DOI:10.17705/1CAIS.03709

${ }^{14}$ Green, B. et al. (2006). Writing narrative literature reviews for peer-reviewed journals: Secrets of the trade. Journal of Chiropractic Medicine, 5(3), 101-117. DOI: 10.1016/S0899-3467(07)60142-6.

${ }^{15}$ Weiss, J. (2011). The Economics of Industrial development. New York: Routledge

${ }^{16}$ Alvarez, S. et al. (2015). The poverty problem and the industrialization solution. Asia Pacific Journal of Management 32(1), 23-37. DOI:10.1007/s10490-014-9397-5

${ }^{17}$ African Development Bank (2014). Regional integration policy and strategy 2014-2023. Abidjan: AFDB

${ }^{18}$ Correa, N. and Kanatsouli, F. (2018). Industrial development in the least developed countries. Vienna: UNIDO. https://www.unido.org/api/opentext/documents/download/12831761/unido-file-12831761

${ }^{19}$ International Monetary Fund (2016). The role of newly industrialized economies in global value chains. Washington, D.C.: IMF. https://www.imf.org/external/pubs/ft/wp/2016/wp16207.pdf

20 Yulek, M. (2018). How nations succeed: Manufacturing, trade, industrial policy and economic development? London: Palgrave Macmillan

${ }^{21}$ Freire, C. (2017). Economic diversification: Explaining the pattern of diversification in the global economy and its implications for fostering diversification in poorer countries, Working Papers Series \#2017-033, Maastricht: Economic and Social Research Institute on Innovation and Technology. https://ideas.repec.org/p/une/wpaper/150.html

${ }^{22}$ World Bank (2019). Economic diversification: Lessons from practice, in World Trade Organisation et al (eds) Aid for trade at glance: Economic diversification and empowerment, Geneva: WTO, pp. 135-160. https://www.wto.org/english/res_e/booksp_e/aid4trade19_chap5_e.pdf

${ }^{23}$ Hare, P. (2008). Institutions and diversification of the economies in transition. Edinburgh: Centre for Economic Reform and Transformation. http://www2.hw.ac.uk/sml/downloads/cert/wpa/2008/dp0804.pdf

${ }^{24}$ Olander, P (2019). Economic diversification and institutional quality-Issues of concentrated interests, Studies in Comparative International Development, 54(1), 1-19. DOI:10.1007/s12116-019-09287-0.

${ }^{25}$ Asian Development Bank (2019). Aid for trade in Asia and the Pacific: Promoting economic diversification and empowerment. Mandaluyong: ADB. https://www.adb.org/publications/aid-trade-asia-pacific-economicdiversification-empowerment.

${ }^{26}$ Mahroum, S. and Al-Saleh, Y. (2018). Economic diversification policies in natural resource rich economies. New York: Routledge

${ }^{27}$ Ali, M. and Cantner, U. (2020). Economic diversification and human development in Europe, Eurasian Economic Review, 10(2), 211-235. DOI: 10.1007/s40822-020-00147-0

${ }^{28}$ World Trade Organisation et al. (2019). Aid for trade at glance: Economic diversification and empowerment. Geneva: WTO. https://www.wto.org/english/res e/booksp e/aid4trade19 e.pdf

${ }^{29}$ Rahim, H. et al. (2014). Globalization and its effect on world poverty and inequality. Global Journal of Management and Business, 8-13. https://www.researchgate.net/publication/280325821_Globalization_and_its_Effect_on_World_Poverty_an d_Inequality

${ }^{30}$ Zaman, K. and Shamsuddin, S. (2018). Linear and non-linear relationships between growth, inequality, and poverty in a panel of Latin America and the Caribbean Countries: A new evidence of pro-poor growth. Social Indicators Research, 136(12), 595-619. DOI:10.1007/s11205-017-1581-9

${ }^{31}$ Kakwani, N. and Hwa Son, H. (2018). Economic growth and poverty. Cheltenham: Edward Elgar Publishing

${ }^{32}$ Organisation for Economic Cooperation and Development (2014). Focus on inequality and growth. Paris: OECD. https://www.oecd.org/social/Focus-Inequality-and-Growth-2014.pdf

${ }^{33}$ McKnight, A. (2019). Understanding the relationship between poverty, inequality and growth: A review of existing evidence, CASEpaper 216/LIPpaper 8, London: Centre for Analysis of Social Exclusion, LSE. https://ideas.repec.org/p/cep/sticas/-216.html

${ }^{34}$ Fauzel, S. (2020) Investigating the impact of trade on poverty reduction in a small island economy. Forum for Social Economics. https://doi.org/10.1080/07360932.2020.1811746 
${ }^{35}$ Gupta, K. and Gupta, A. (2020) Enhancing productivity for poverty reduction in India. Asian Developing Bank: ADB. http://dx.doi.org/10.22617/BRF200117-2

${ }^{36}$ Maki, A. et al. (2015). Poverty, inequality and growth in developing countries: Theoretical and empirical approaches. New York: Routledge

${ }^{37}$ United Nations Development Programme (2016). Reducing inequality within and among countries. New York: UNDP. https://www.un.org/sustainabledevelopment/inequality/ 